University of Louisville

ThinkIR: The University of Louisville's Institutional Repository

Faculty Scholarship

2019

Dismantling Structural Inequality: Lock Ups, Systemic Chokeholds, and Race-Based Policing - A Symposium Summary

Cedric Merlin Powell

University of Louisville, cedric.powell@louisville.edu

Laura R. McNeal

University of Louisville, laura.mcneal@louisville.edu

Follow this and additional works at: https://ir.library.louisville.edu/faculty

Part of the Civil Rights and Discrimination Commons, Criminology and Criminal Justice Commons, Inequality and Stratification Commons, and the Law and Race Commons

Original Publication Information

Forthcoming in University of Louisville Law Review

This Article is brought to you for free and open access by ThinkIR: The University of Louisville's Institutional Repository. It has been accepted for inclusion in Faculty Scholarship by an authorized administrator of ThinkIR: The University of Louisville's Institutional Repository. For more information, please contact thinkir@louisville.edu. 


\title{
DISMANTLING STRUCTURAL INEQUALITY: LOCK UPS, SYSTEMIC CHOKEHOLDS, AND RACE-BASED POLICING-A SYMPOSIUM SUMMARY
}

\author{
Cedric Merlin Powell* \\ Laura McNeal ${ }^{* *}$
}

The prominence of the carceral state in American society serves to undermine basic principles of democracy and justice, disproportionately displacing people of color and excluding them from all viable avenues of citizenship. Three recent books explore the criminal justice system and structural inequality. In Chokehold, Professor Paul Butler explores the pervasive narrative of Black male criminality and violence, which serves to rationalize the criminalization of Black men. ${ }^{1}$ The Chokehold is a form of legitimized state violence in policing communities of color and a tool of systemic oppression - the state is authorized to control African-American men who are viewed as threats to the social order. Professor James Forman Jr.'s Locking Up Our Own uncovers the disconcerting history of how Black public officials, full of hope and promise as Black mayors were elected for the first time in major cities, joined the "War on Crime" and promoted policies that contributed to the disproportionate incarceration rates that are a defining feature of the criminal justice system today. ${ }^{2}$ Policing the Black Man, a collection of essays edited by Professor Angela J. Davis, offers a compelling account of how disproportionate impact is prevalent throughout the criminal justice system from arrest through sentencing. ${ }^{3}$

Foregrounding these texts as the starting point for discussion and unpacking the systemic intricacies of structural inequality, this symposium explored three interlocking oppressive features of the criminal justice system:

\footnotetext{
* Cedric Merlin Powell, Professor of Law, University of Louisville Louis D. Brandeis School of Law. B.A. Oberlin College; J.D. New York University School of Law. Co-Organizer, Inaugural Dismantling Structural Inequality Symposium: Lock Ups, Systemic Chokeholds, and Race-Based Policing, March 23, 2018.

** Laura McNeal, Associate Professor of Law, University of Louisville Louis D. Brandeis School of Law. J.D. Washington University St. Louis; Ph.D., Illinois State University. Co-Organizer, Inaugural Dismantling Structural Inequality Symposium: Lock-Ups, Systemic Chokeholds, and Race-Based Policing, March 23, 2018.

${ }^{1}$ See Paul Butler, Chokehold: Policing Black Men (2017).

2 See JAMES Forman, JR., LOCKING Up OUR Own: CRIME AND PUNISHMENT IN BLACK AMERICA (2017).

3 See Angela J. Davis et al., Policing the Black Man: Arrest, Prosecution, and IMPRISONMENT (Angela J. Davis ed., 2017).
} 
(i) the societal presumption of Black criminality and violence, and how this rationalizes and reinforces a structural chokehold on African-Americans; (ii) the complex systemic relationships between Black leadership, crime policy, and decision-making leading to disproportionate incarceration rates for African-American males; and (iii) systemic practices from racial profiling to a flawed grand jury system that insulates unjustified violence and police misconduct from scrutiny at trial.

Dismantling Structural Inequality brings together four distinct conceptual approaches to theorizing the disproportionate impact of the criminal justice system. In The Structural Dimensions of Race: Lock Ups, Systemic Chokeholds, and Binary Disruptions, Professor Cedric Merlin Powell offers a comprehensive review and critique of Professor Butler's Chokehold and Professor Forman's Locking Up Our Own. By integrating both texts in a comparative analysis, Professor Powell unpacks the paradox of Black decision-making power, how systemic racism deploys neutral enforcement rhetoric to justify and reinforce the disproportionate impact that is a defining feature of the carceral state, and how the permanence of racism undergirds a system that consistently evolves to preserve the oppressive power of structural inequality. By engaging Professor Butler's radical and transformative call for the demolition of the current criminal justice system and Professor Forman's nuanced emphasis on incremental structural change, Professor Powell's essay mines the gap between these two distinct approaches and offers a conceptual framework that draws on both approaches. What is particularly compelling is how both Chokehold and Locking Up Our Own offer new ways of theorizing intersectionality within the context of Black maleness and the presumption of criminality and Black power and how it operates; both books reject essentialist constructions of how race, gender, and power circulate in the criminal justice system and beyond.

Advancing a powerful, provocative, and insightful critique of Chokehold, Professor Nirej Sekhon's The Chokehold posits that the metaphoric resonance of the Chokehold has great evocative power and conceptual limitations. He notes "the [Chokehold] metaphor has the problem of being very particularistic, returning the reader's mind to one specific police practice." ${ }^{4}$ This is an important point because it illustrates how the Chokehold will be received as not only a doctrinal tool for analyzing structural inequality, but as an organizing principle to dismantle the criminal justice system itself. In analyzing the Chokehold's receptive power,

${ }^{4}$ Nirej Sekhon, The Chokehold, 57 U. LouisviLLE L. REV. 43, 43 (2018). 
Professor Sekhon uncovers what he argues is a key limitation and tension of the Chokehold metaphor - it calls for radical structural change, including defensive violence, but retreats, to a certain extent, from these calls to take up the struggle to abolish the carceral state. Concluding that "Professor Butler is not one to shy away from the radical implications of his arguments, but it does seem like he has done so in Chokehold," 5 Professor Sekhon ends his review with the hope that future scholarship will engage directly with defensive violence, resistance, and struggle.

Drawing upon her experiences as a public defender in New Orleans and as a Pan African Studies scholar, Professor Elizabeth Jones chronicles how structural inequality functions on the ground in The Profitability of Racism: Discriminatory Design in the Carceral State. With Professor Forman's Locking Up Our Own as a conceptual lens to integrate her experience as a defense attorney and the assessment of Black decision-making power that Professor Forman offers in his book, Professor Jones offers a wide-ranging critique of the criminal justice system. Emphasizing the structural magnitude of racist oppression, Professor Jones observes that, while she agrees with Professor Forman's theory that African-American policymakers contributed to the perpetuation of mass incarceration, "this is because larger systemic processes in the political economy cause the carceral state to function in this way irrespective of the actors. As a result of discriminatory design, you can put any person of any color in powerful positions within the carceral state and it will continue to replicate racially disparate outcomes." ${ }^{\prime 6}$ Professor Jones's engaging, experiential, and doctrinal contribution to this symposium is important in framing how structural inequality can be dismantled.

In Freedom and Prison: Putting Structuralism Back into Structural Inequality, Professor Anders Walker canvasses the structural inequality scholarship in the wake of Michelle Alexander's groundbreaking, The New Jim Crow: Mass Incarceration in the Age of Colorblindness, and advances a powerful critique of the limitations of the literature. Specifically, how structuralism is conceptualized has often focused narrowly on invidious institutional intent rather than "whether policies that lacked racial animus may have contributed to mass incarceration." "This unresolved theoretical question of racial animus leaves any conceptualization of structural inequality incomplete. Professor Walker seeks to illustrate how a critique of

\footnotetext{
${ }^{5} I d$. at 56

${ }^{6}$ Elizabeth Jones, The Profitability of Racism: Discriminatory Design in the Carceral State, 57 U. LOUISVILLE L. REV. 61, 87 (2018).

7 Anders Walker, Freedom and Prison: Putting Structuralism Back into Structural Inequality, 57 U. LOUISVILLE L. REV. 89, 90 (2018).
} 
Professor Alexander's theory can lead us to a "more genuinely structuralistrather than post-structuralist - account of mass incarceration in the United States." "That is, Professor Walker advocates a conceptual move away from discriminatory intent (racial animus) and human nature to a comprehensive and critical assessment of how structural inequality functions. Indeed, an important component of Professor Walker's theoretical approach is a critique of how an ostensibly neutral concept, like liberal individualism, has been used and exploited by the Court to preserve structural inequality by protecting segregated communities, reversing any gains made through affirmative action by privileging reverse discrimination claims by whites, and gutting voting rights, all in the name of state power and individual liberty. These "neutral" concepts are particularly devastating in the criminal justice system, so it is imperative, as Professor Walker argues, that a robust theory of structuralism be returned to our doctrinal discussions of structural inequality.

These four essays represent the first two panels of the symposium. A final panel at the symposium highlighted systemic practices underlying structural inequality in the criminal justice system. Professor Angela Davis utilized her thought-provoking anthology, Policing the Black Man, to provide a theoretical framework for the panel to critique the historical roots of structural inequality within the criminal justice system and provide a platform for examining the fundamental changes necessary to promote comprehensive reform. Professor Davis focused on her specialty, prosecutors, and how their unbridled authority perpetuates our current system of mass incarceration. Complementing the comprehensive examination of prosecutorial power espoused in Professor Davis's presentation, Professor Laura McNeal offered some preliminary observations from her national study of prosecutorial behavior. The findings from Professor McNeal's national prosecuting attorney study, conducted through Harvard Law School, provided further insight into dismantling structural inequality by highlighting the pressures, incentives, and structural factors that affect the decisions of prosecutors with the highest racial disparities in prosecution and sentencing. As the coalition to dismantle mass incarceration grows in numbers and strength, attention is increasingly being focused on racial profiling, the enormous power and discretion wielded by prosecutors, and the role of implicit bias in perpetuating racial injustices. The findings of this national study provided invaluable insight regarding how prosecutors are uniquely positioned to

${ }^{8} I d$. at 91 . 
reduce our current prison population and shrink the overall criminal justice apparatus in this country.

Professor McNeal posits that comprehensive criminal justice reform in this country must encompass fundamental changes in the incentive systems and cultures of prosecutors' offices. The study's findings suggest that for substantive criminal justice reform to occur, prosecutors must lead the way. First, the culture of prosecuting attorneys' offices must move away from an emphasis on "winning" toward one of "justice" and an understanding of the impacts of their prosecutions on individuals and the broader society. Second, we must change the way in which prosecutors are recruited and trained to promote diversity within the field, minimize the effects of biases in prosecutorial decisions, and help prosecutors gain a more nuanced understanding of human behavior and the unique needs of the communities in which they serve. Finally, the study's findings underscore the need for more transparency in prosecutorial decision-making and incentive structures to increase their accountability. Panelist, Ed Monahan, Former Public Advocate of Kentucky, further demonstrated the importance of implementing the proposed prosecutorial reform measures from the Harvard study through his presentation. As a national policy expert and advocate for criminal justice reform, Mr. Monahan offered a wide-ranging discussion and critique of prosecutorial practices, systemic disparities, and reform efforts locally, statewide, and nationally.

It is our hope that this symposium will be one of many important steps toward dismantling structural inequality and constructing a system of justice based on proportionality, substantive equality, and justice. 
